Studia Oecumenica 17 (2017)

DOI: $10.25167 / \mathrm{SOe} / 17 / 2017 / 149-164$

RAJMUND PORADA

Wydział Teologiczny UO

\title{
„Skok wiary” w Lutrowej nauce o usprawiedliwieniu
}

\author{
"Leap of Faith" in Luther's Doctrine of Justification
}

\begin{abstract}
The article presents Luther's teaching on justification by faith and its theological implications. In the doctrine of justification, the Reformer of Wittenberg found a way to free itself from doubts about salvation, concluding that not deeds and confession of sins before God, but only faith makes righteousness before God. Luther's new perspective on the relation of man to God can be called a "leap of faith". According to the Father of the Reformation, faith itself is enough for being sure of one's own salvation. In this view, faith is identified with salvation. The basis of Luther's conception of faith lies in his theological anthropology and its implications have become evident in ecclesiology.
\end{abstract}

Keywords: Luther, doctrine of justification, faith, deeds, salvation, Church.

\section{Streszczenie}

Artykuł stanowi prezentację nauczania Lutra na temat usprawiedliwiającej wiary i wynikających stąd niektórych teologicznych implikacji. W nauce o usprawiedliwieniu Reformator z Wittenbergi znalazł sposób na uwolnienie się od wątpliwości w kwestii zbawienia, dochodząc do wniosku, że nie uczynki i wyznawanie przed Bogiem swoich niepowodzeń, lecz jedynie wiara czyni sprawiedliwym przed Bogiem. Zaproponowaną przez Lutra nową perspektywę spojrzenia na relację człowieka do Boga można nazwać „skokiem wiary”. Według Ojca Reformacji sama wiara wystarczy, by być pewnym swego zbawienia w sposób ostateczny. W tym ujęciu wiara utożsamia się z pewnością zbawienia. Podłoże Lutrowej koncepcji wiary znajduje się w jego teologicznej antropologii, zaś jej implikacje stały się widoczne w eklezjologii.

Słowa kluczowe: Luter, nauka o usprawiedliwieniu, wiara, uczynki, zbawienie, Kościół.

Pięćsetlecie Reformacji skłania do ponownego przebadania jej postulatów, wiodących idei i doktrynalnych „odkryć”. Jednym z nich była Lutrowa nauka o usprawiedliwieniu, która stała się centrum luterskiej i luterańskiej teologii, a także jednym z podstawowych wyróżników Reformacji. Mimo że znaczącą rolę w jej powodzeniu odegrały ówczesne ogólnoeuropejskie, cesarskie, książę- 
ce i polityczne uwarunkowania, to nie podważa to jednak przekonania, że ruch ten w swej istocie miał charakter religijny, teologiczny, duchowy i duszpasterski. Choć nie można pomijać faktu, że wdrożeniu Reformacji w wielu miejscach towarzyszył polityczny i prawny nacisk, a także intrygi i niepokoje, to jednak jej ostateczne powodzenie wynika z tego, że oferowała ona religijną odpowiedź na pytania tamtej epoki i oznaczała duchowe przebudzenie ${ }^{1}$. Centralnym przesłaniem luterskiego orędzia stała się nauka o usprawiedliwieniu grzesznika jedynie przez wiarę w Chrystusa. Głoszenie tej nauki skierowane było przeciwko Kościołowi, który - według przekonania Reformatora - nauczał, że człowiek może wysłużyć sobie zbawienie przez dobre uczynki. Zgodnie z tym nauczaniem, zdaniem Lutra, Kościół zorganizował cały system zbawienia. Lutrowa odpowiedź była więc zdecydowana, a nauka o usprawiedliwieniu została podniesiona do rangi nadrzędnego czynnika i kryterium całego kościelnego nauczania². O znaczeniu tej nauki w tamtym czasie świadczy jej miejsce w nauczaniu Soboru Trydenckiego, który sformułował dekret o usprawiedliwieniu - jeden z najważniejszych dokumentów tamtego soboru.

W nauce o usprawiedliwieniu Luter w szczególny sposób wyeksponował znaczenie wiary, bez której nie może być mowy o usprawiedliwieniu. Z biografii Ojca Reformacji wiadomo, że jako młodego mnicha szczególnie zajmowało go pytanie o pewność zbawienia. W reformacyjnym „odkryciu” nauki o usprawiedliwieniu uwolnił się on od wątpliwości, czy sakramentalne pojednanie $\mathrm{z}$ Bogiem jest w stanie dać ostateczną pewność co do stanu zbawienia. Luter zrozumiał, że uczynki i wyznawanie przed Bogiem swoich niepowodzeń nic tu znaczy, a jedynie wiara czyni sprawiedliwym wobec Boga. Sama wiara wystarczy, by być pewnym swego zbawienia w sposób ostateczny i na zawsze ${ }^{3}$. Mocny akcent, który położył on na roli osobistej wiary wierzącego, stanowi niewątpliwie znaczący wyróżnik jego koncepcji. Zarówno praktyki religijne tamtego czasu, które doprowadziły do kontrowersji wokół odpustów, jak i Lutrowa „pasja” dla nauki o usprawiedliwieniu wpłynęły modyfikująco na jego rozumienie i definiowanie wiary. Celem artykułu jest przedstawienie nauczania Lutra na temat usprawiedliwiającej wiary i wynikających stąd niektórych teologicznych implikacji.

1 J.E. VerCRUYSSE, Luthers Reformation und ihre Bedeutung für die katholische Kirche, ZKTh 121 (1999), 31-32.

${ }^{2}$ Die Promotionsdisputation von Palladius und Tilemann. Die Disputation. Praefatio Lutheri: Articulus iustificationis est magister et princeps, dominus, rector et iudex super omnia genera doctrinarum, qui conservat et gubernat omnem doctrinam ecclesiasticam et erigit conscientiam nostram coram Deo. Sine hoc articulo mundus est plane mors et tenebrae (WA 39 I, 205, 2-5).

${ }^{3}$ B. WALD, Glaubensgewissheit und gute Werke. Martin Luther als Wegbereiter des utilitaristischen Moralprinzips, w: S. Kopp, W. THÖNISSEN (red.), Mehr als friedvoll getrennt? Ökumene nach 2017, Freiburg im Br. 2017, 143. 


\section{Kontrowersje wokół odpustów}

Pierwsza sporna kwestia, którą podniósł Luter i która stała się zapalną iskrą dla wybuchu Reformacji, związana była z kazaniem dominikanina Johanna Tetzela na temat odpustów. W tle nauczania na temat odpustów znajdowało się przekonanie o konieczności zadośćuczynienia za każde przewinienie czy moralny występek. Grzech jako przewinienie wobec Boga domagał się wynagrodzenia, satysfakcji, nawet wtedy, gdy został on już odpuszczony w spowiedzi. Formami takiej satysfakcji mogły być pielgrzymki, modlitwy, ofiary, posty, śluby, szczególnie przez fundowanie ofiar mszalnych z okazji kolejnych rocznic. Gdyby na eschatologicznym sądzie owe zadośćuczynne dzieła okazały się niewystraczające, grzesznik musiał odpokutować należne kary w czyśćcu. „Miejsce" to nie byłoby jednak formą arbitralnej kary Bożej, lecz szansą uwolnienia od winy i przygotowania się do przebywania we wspólnocie z Bogiem w niebie. W oparciu o tak wypracowaną teologiczną konstrukcję nie było wiadomo, czy podjęte działania okażą się wystraczające i jak wobec tego wygląda sytuacja zbawcza wierzącego. Oczywiste jedynie wydawało się, że większą pokutę niż to było konieczne spełnili święci, przyczyniając się do powstania „nadwyżki”, która przypada Kościołowi jako wspólnocie świętych. Wraz z dziełem zbawczym Chrystusa stanowi ona skarbiec Kościoła, w którym udział mają wszyscy wierni. Skarbcem tym zarządza papież, który w formie odpustów udziela jego dobrodziejstw potrzebującym członkom Kościoła. Pierwotnym zamysłem idei odpustów było uwolnienie wiernych od lęku przed piekłem poprzez wzbudzenie zaufania do świętych, którzy zanoszą modlitwę wstawienniczą za Kościół. Idea ta stała się jednak problematyczna, gdy zaczęto wiązać ją z transakcjami finansowymi. Powstało wrażenie, jakoby można było kupić zbawcze zasługi innych osób. I mimo że dzięki zróżnicowaniu stawek opłat ze względu na zamożność kupujących także biedni mogli zyskiwać odpusty, instytucja odpustów już w XV w. stała się przedmiotem zgorszenia. Tymczasem w XVI w. w Rzymie brakowało pieniędzy na budowę Bazyliki św. Piotra. Papieże jako renesansowi władcy zaangażowali najlepszych i najdroższych artystów. Albrecht Hohenzollern, arcybiskup Moguncji, był wysoko zadłużony w Rzymie ze względu na nominację biskupią i dyspensę za kumulowanie urzędów, gdyż był już arcybiskupem Magdeburga. Aby móc spłacić zaciągnięty w tym celu kredyt, zezwolił on na sprzedaż ustanowionego w Rzymie odpustu św. Piotra, przy czym połowa zysku miała przypaść jemu samemu. Gdy Luter usłyszał w kazaniu Tetzela o odpustach, nie znał szczegółów, które kryły się za tą praktyką. Sam kaznodzieja też zniekształcał sens odpustów, tak by jego oferta była atrakcyjna. Obiecywał bowiem nie tylko uwolnienie od kar za grzechy, lecz także odpuszczenie grzechów, nawet w odniesieniu do zmarłych. Można było w ten sposób rzekomo wykupić 
zmarłych krewnych z cierpień czyśćcowych. Odpusty miały także działać profilaktycznie i strzec przed karami za przyszłe grzechy ${ }^{4}$.

Sprawa odpustów wpisywała się w szerszy kontekst pobożności późnego średniowiecza, naznaczonej oczekiwaniem powtórnego przyjścia Chrystusa na sąd. Życie wiary znacząco było zdominowane przez kwestię zbawienia. Strach przed sądem Bożym, czyśćcem, piekłem i troska o los zmarłych był głęboko zakorzeniony w świadomości wiernych. Na kształt pobożności wpływały więc w dużej mierze zabiegi zmierzające do stłumienia bądź osłabienia owego strachu. Na tym podłożu dobrze zakorzeniła się idea zasługiwania na zbawienie oraz doktryna i praktyka odpustów. W codziennym praktykowaniu pobożności podkreślano - także z obawy o finansowe dochody - znaczenie uczynków i sakramentów, stawiając je w konkurencji do wiary i zaufania Chrystusowi ${ }^{5}$. Spowiedź jawiła się jako najważniejszy sakrament. Wyeksponowano szczególnie aspekt zadośćuczynienia. Rodziło się jednak pytanie o jego wystarczający stopień. Odpusty miały w tych okolicznościach uwolnić od zbytniej troski w tym względzie.

Luter zakwestionował ten typ nauczania i wynikające z niego praktyki, eksponując ideę zbawienia z łaski przez wiarę. Jako duszpasterz dostrzegał z pewnością osłabianie się pokutnej postawy wśród wiernych, którzy zaczęli powoływać się na odpusty i dostrzegać w nich rodzaju zabezpieczenia zbawienia u Boga. Głoszenie odpustów było więc $\mathrm{w}$ przekonaniu Lutra niezgodne $\mathrm{z}$ chrześcijańskim orędziem. Jako teolog czuł się z kolei, ze względu na troskę o czystość nauczania, zobowiązany do jasnego wykładu. Dlatego zwrócił się do bpa Albrechta Hohenzollerna z prośbą o instrukcje dotyczące przepowiadania na temat odpustów. Luter ich nie odrzucał, chciał jednak chronić się przed fałszywymi wyobrażeniami na ten temat. W tym celu opublikował 31 października $1517 \mathrm{r}$. swoje 95 tez, które uruchomiły ruch reformacyjny ${ }^{6}$.

Można wskazać jeszcze na inne czynniki, które odegrały znaczącą rolę w reformatorskim nastawieniu Lutra. W rozważaniach nad pokutą i wnioskami dotyczącymi wiary nie bez znaczenia było zainteresowanie - pod wpływem swego zakonnego przełożonego Staupitza - tradycją mistyczną i jej personalistycznym podejściem do życia religijnego, przeciwstawionym rozpowszechnionej wówczas pobożności, bazującej silnie na zewnętrznym wymiarze praktyk i rytuałów. Dzięki temu silna była u Lutra wola przezwyciężenia skostniałej religijności,

${ }^{4}$ P. Neuner, Martin Luthers Reformation. Eine katholische Würdigung, Freiburg im Br. 2017, $115-116$.

5 J.E. VeRCRUYSSE, Luthers Reformation, 34.

${ }^{6}$ Ł. BARański, J. SoJKa, Reformacja, t. I: Historia i teologia luterańskiej odnowy Kościoła w Niemczech w XVI wieku, Bielsko-Biała 2016, 72-74; P. Neuner, Martin Luthers Reformation, 117; A.A. NAPIÓRKOWSKI, Usprawiedliwienie naczelnym kryterium reformacyjnej odnowy Kościoła, w: TENŻE (red.), Reformatorzy a Kościót rzymski, Kraków 2017, 114. 
wypełnionej przepisami i środkami łaski, które nagromadziły się w niej przez wieki $^{7}$. Teologia scholastyczna wbudowała charytologię w skomplikowany system stopniowalnej przyczynowości oraz w rozważania dotyczące naturalnych możliwości człowieka i jego wolnej woli, co w efekcie prowadziło do jej marginalizacji. Wittenberski Reformator zapragnął wydobyć ją z marginesu i ustanowić punktem odniesienia dla swego teologicznego myślenia. Jego nauczanie na temat nauki o usprawiedliwienia można postrzegać jako alternatywę wobec nauczania o odpustach. Także ono opiera się na określonym rozumieniu pokuty, przy czym nie w kategoriach satysfakcji, lecz Bożej obietnicy zbawienia. Nauka ta głosi, że człowiek zostaje usprawiedliwiony nie mocą własnych uczynków, lecz dzięki miłosierdziu Bożemu, które daje mu udział w zbawieniu wyłącznie dzięki wierze. Wittenberski Reformator krótko przed śmiercią osobiście odniósł się do tego, co było motywem przewodnim jego protestu i co stało się treścią jego nauczania.

\section{2. „Odkrycie" nauki o usprawiedliwieniu}

Kluczem do zrozumienia Lutrowej pasji dla nauki o usprawiedliwieniu jest jego autobiograficzna wypowiedź zawarta we wprowadzeniu do pierwszej części jego Opera omnia ${ }^{8}$. W tekście tym, który powstał w 1545 r., a więc kilka miesięcy przed śmiercią, Luter - w retrospektywnym spojrzeniu na swoje życie i nauczanie - pisze o tzw. przeżyciu w wieży (Turmerlebnis) ${ }^{9}$ jeszcze z czasów pobytu w klasztorze augustiańskim w Wittenberdze i swym „odkryciu” ewangelicznego znaczenia wyrażenia iustitia Dei w Liście do Rzymian ${ }^{10}$. Niezależnie od oceny opisywanego przez Lutra przeżycia, jego relacja i symboliczna interpretacja tamtego wydarzenia mają w pewnym sensie założycielski charakter dla tradycji luterańskiej. Istotne znaczenie ma tu fakt, że jest to świadectwo, a zarazem wspomnienie już zaawansowanego wiekowo człowieka dotyczące wyda-

7 Zob. V. Leppin, Martin Luther. Vom Mönch zum Feind des Papstes, Darmstadt 2013; P. NeuNER, Martin Luthers Reformation, 22; Ł. BARAŃsKi, J. SoJKA, Reformacja, 39-42.

${ }^{8}$ Vorrede zum ersten Bande der Gesamtausgaben seiner lateinischen Schriften, Wittenberg 1545; WA 54, 185, $12-187,2$.

9 „Historyczność” tego przeżycia jest nieraz podważana ze względu na trudność precyzyjnego wskazania konkretnej daty. Przyjęło się traktować je jednak jako moment swoistego „nawrócenia” Lutra w sensie nowego odkrycia Ewangelii. Dzisiaj raczej podważa się taki charakter tego przeżycia, wskazując, że owo odkrycie Ewangelii miało raczej charakter procesu, stopniowego rozwoju wewnętrznego, któremu towarzyszyły wprawdzie różne wstrząsy, jednak nie nagły przełom. Zob. np. V. Leppin, Martin Luther, 155

${ }^{10}$ Por. P. JASKÓŁA, Ku jedności w Chrystusie. Wybrane zagadnienia z problematyki ekumenicznej i dogmatycznej, Opole 2016, 45; Ł. BARAŃsKI, J. SoJKA, Reformacja, 112; B. MiLERSKI, Miejsce pojednania w soteriologii Marcina Lutra, w: M. UGLorz (red.), Teologia wiary. Teologia ks. Marcina Lutra i ksiag wyznaniowych Kościoła luterańskiego, Bielsko-Biała 2007, 118. 
rzenia, które wspomina jako przełomowe w jego życiu i kiedy dokonał się jego „reformacyjny zwrot”. Osobista relacja Reformatora sprawia, że nie ma powodów, by podważać prawdziwość jego słów, nawet jeśli bliższe prawdy wydaje się założenie, że owo przeżycie nie miało tyle charakteru nawrócenia, ile nabycia nowej świadomości w odniesieniu do tego, co było od dawna przedmiotem jego medytacji w życiu klasztornym i intelektualnego namysłu w prowadzonej wówczas pracy naukowej ${ }^{11}$.

W latach 1515-1516 Luter prowadził wykłady na temat Listu do Rzymian. Jak wynika z jego słów, w wyniku teologiczno-egzegetycznych rozważań doszedł do nowego rozumienia związku między słowem ,ewangelia”, rozumianym w sensie dobrej nowiny, a określeniem iustitia Dei w Rz 1,16-17. Odnalazł tu dostrzegane już wcześniej w czasie lektury psalmów potwierdzenie wniosku, że zbawienie dochodzi do skutki wyłącznie dzięki Bożemu działaniu. Swoje odkrycie wyraził w terminach zaczerpniętych z języka mistycznego, mimo że nie miało one takiego charakteru. Musiało mieć jednak silny wydźwięk emocjonalny. Jak sam bowiem pisze, to miejsce biblijne doprowadzało go wcześniej do wątpienia w zbawienie własnej duszy: ibi iustitiam Dei coepi intelligere eam ${ }^{12}$. Zdobyte zrozumienie skłoniło go też do dalszych poszukiwań w tej materii tak w Piśmie Świętym, jak i u Augustyna, oraz stało się kamieniem węgielnym dla nowego sposobu teologicznego myślenia ${ }^{13}$.

W ówczesnych okolicznościach nauka o usprawiedliwieniu stała się jednocześnie „batem” na Kościół rzymski, jego autorytet i nauczanie, babilońską niewolę sakramentów, wiele zwyczajów i praktyk, w których Luter dostrzegał wolę poszukiwania samousprawiedliwienia poprzez osobiste uczynki i dzieła oraz stawiania tego, co ludzkie, pomiędzy wiarę i Boga. Nie oznaczało, że Luter dążył do rebelii nie licząc się z wymogami prawdy. Przeciwnie, dla wittenberskiego Reformatora kwestie prawdy i prawowierności pozostawały żywotne, jednakże nie pojmował ich w sensie dogmatycznej poprawności wypowiedzi wiary, lecz w perspektywie egzystencjalnej. Prawdą jest znajomość i kroczenie drogami wiary w Chrystusa. W wierze rozgrywa się sprawa zbawienia. Kto w błędny sposób rozumie wiarę i przyjmuje pogląd, że może osiągnąć zbawienie poprzez własne zasługi, zbacza z właściwej drogi i nie trwa w prawdzie. Co więcej, odbiera Bogu należną cześć, przywłaszczając sobie zasługi i dary pochodzące od Boga. W ten sposób wierzący oddaje cześć samemu sobie, czyniąc z siebie bożka i grzesząc jednocześnie przeciwko pierwszemu przykazaniu. Wolą Lutra było zaś danie świadectwa o wielkim

11 J.E. VERCRUYSSE, Luthers Reformation, 33.

12 WA $54,186,5$.

13 J.E. VerCRUYSSE, Luthers Reformation, 33; S. LAMPE-DENSKY, Reformation-verdrängt, verhindert, verweigert. Erneuerung und Befreiung in den frühen Jahren des 16. Jahrhunderts, Berlin 2017, 187. 
majestacie Boga, blasku pierwszego przykazania, autorytecie Bożego słowa, łaskawym miłosierdziu Bożym, wierze i zaufaniu oraz wolności chrześcijanina ${ }^{14}$. Związane było to z wezwaniem do rozwijania biblijnej i osobistej pobożności, odrzucającej wszelką hipokryzję, rytualizm i koncentrację na tym, co zewnętrzne.

\section{Usprawiedliwienie przez wiarę}

By uchwycić z całą ostrością istotę zmagań Lutra o właściwe rozumienie nauki o usprawiedliwieniu, a zwłaszcza podkreślaną przez niego rolę wiary w procesie usprawiedliwienia, należy sięgnąć do pism, w których wittenberski Reformator kładzie właściwe podwaliny pod swą doktrynę. Początkiem sporu o rozumienie usprawiedliwienia z udziałem Lutra były jego obszerne rozważania dotyczące sakramentu pokuty ${ }^{15}$. Temat ten przewija się w pismach Lutra redagowanych już przed 1518 r., zwłaszcza w kontekście tez o odpustach. Przygotowując się do dysputy nad formułowanymi przez siebie tezami, Luter sporządził odpowiednie wyjaśnienia i uzasadnienia (declarationes ac probationes; Erklärungen und Beweise) dla swych poglądów. Reagując na niezrozumienie lub błędne interpretacje swoich wypowiedzi, zdecydował się na ich publikację. W tym celu w lutym 1518 r. zwrócił się do bpa Hieronima z Brandenburga, który sprawował nadzór nad uniwersytetem w Wittenberdze, o pozwolenie na ich publikację. W międzyczasie ukazało się Lutrowe „Kazanie o odpuście i łasce” (Sermon von Ablass und Gnade). Biskup obawiając się, że Luter może wbrew jego woli opublikować przesłane mu pismo, przez pośrednictwo jednego z zakonnych zwierzchników początkowo poprosił Lutra o wstrzymanie się z publikacją, wkrótce jednak uznał, że lepiej będzie, jeśli tezy na temat odpustów nie pozostaną niewyjaśnione. 30 maja tego samego roku Luter po dokonaniu koniecznych korekt przesłał swe „uzasadnienia” (Beweise) do swego zakonnego przełożonego, Jana Staupitza, by ten skierował je do papieża. W piśmie przesłanym do Staupitza Luter stwierdza m.in., że źródłem prawdziwej pokuty jest miłość Boga: poenitentia vera non est, nisi quae ab amore iusticiae et dei incipit ${ }^{16}$. Wittenberski Reformator nie zmierzał jednak do odrzucenia sakramentalnego wymiaru pokuty, przeciwnie - zaliczał ją niewątpliwie do sakramentów ${ }^{17}$. Najważniejsze pytanie stawiane przez Lutra dotyczyło możliwości dostąpienia odpuszczenia grzechów. W czasach Lutra teologia reprezentowała stanowisko, że Bóg odpuszcza człowiekowi grzechy, jeśli ten

${ }^{14}$ Zob. Duży katechizm, w: Wybrane księgi symboliczne Kościoła Ewangelicko-Augsburskiego, Warszawa 1980, 84 .

${ }_{15}$ Zob. WA 1, 525-628.

16 WA 1,525, 11-12.

${ }^{17}$ De captivitate Babylonica ecclesiae. Praeludium, WA 6, 501, 34; 509, 5; 543, 4 - 549, 19. 
w akcie bezwarunkowej miłości Boga żałuje za nie. Odpuszczenie grzechu było więc skutkiem podejmowanego żalu, na który Bóg pozytywnie odpowiedział. Zadaniem szafarza sakramentu, czyli kapłana, było jedynie potwierdzenie i zadeklarowanie w akcie absolucji odpuszczenia grzechu, które dokonało się poprzez akt żalu. To przekonanie wynikało z nominalistycznej teorii, według której temu, kto czyni to, co leży w jego mocy, Bóg nie odmawia swojej łaski ${ }^{18}$. Luter podejmując refleksję nad późnośredniowieczną nauką o pokucie, zrozumiał, że ów żal opiera się na obietnicy Bożej, którą człowiek przyjmuje w wierze. W wyjaśnieniu 7. tezy na temat odpustów Luter twierdził, że żaden człowiek nie może być usprawiedliwiony przed Bogiem inaczej, jak tylko przez wiarę: Infallibilis est veritas, quod nullus est iustus nisi qui credit in deum ${ }^{19}$. Za niezbędny warunek uznał wiarę w swe usprawiedliwienie i odrzucenie wątpliwości odnośnie do uzyskania łaski: Neminem iustificari posse nisi per fidem, sic scilicet, ut necesse sit, cum certa fide credere sese iustificari et nullo modo dubitare, quod gratiam consequatur ${ }^{20}$. Autorzy dokumentu Od konfliktu do komunii, prezentując stanowisko Lutra, wyjaśnili, że wiara - w przekonaniu Reformatora - jest jedyną właściwą odpowiedzią na daną w słowie Bożą obietnicę: „Człowiek jest wezwany do patrzenia poza samego siebie - jedynie na Słowo Bożej obietnicy, któremu jest obowiązany w pełni zaufać. Ponieważ wiara ma swój fundament w obietnicy Chrystusa, daje ona wierzącemu całkowitą pewność (Gewissheit) zbawienia. Nie zaufać temu Słowu oznaczałoby czynić z Boga kłamcę albo kogoś niegodnego zaufania. Stąd też niewiara jest w ujęciu Lutra największym grzechem wobec Boga"21.

Tak wyeksponowana przez Ojca Reformacji wizja wiary i nauka o pewności usprawiedliwienia spotkała się z reakcją Soboru Trydenckiego. Ojcowie soborowi potępili tę koncepcję, określając ją mianem ,próżnej ufności” (vana fiducia) ${ }^{22}$. Jednocześnie stwierdzili, iż „(...) nie należy twierdzić, że ci, którzy prawdziwie zostali usprawiedliwieni, winni bez żadnej wątpliwości samych siebie zapewniać, iż zostali usprawiedliwieni. Następnie [nie należy twierdzić], że nikt nie doznaje odpuszczenia grzechów i usprawiedliwienia, tylko ten, kto wierzy z całkowitą pewnością, iż doznał odpuszczenia grzechów i usprawiedliwienia oraz że jedynie dzięki tej wierze dokonuje się odpuszczenie i usprawiedliwienie, jak gdyby ten, kto w to nie wierzy, wątpił w obietnice Boże i skuteczność

${ }^{18}$ Facienti quod in se est, Deus non denegat gratiam; za: Od konfliktu do komunii, nr 102 . Jak wskazuje T. Dieter, cytowane zdanie pochodzi od Gabriela Biela. Zob. T. Dieter, Der junge Luther und Aristoteles. Eine historisch-systematische Untersuchung zum Verhältnis von Theologie und Philosophie, Berlin - New York 2001, 183-187.

${ }^{19}$ WA 2, 13, 12-13.

${ }^{20}$ WA 2, 13, 7-8.

${ }^{21} \mathrm{Nr} 103$.

22 BF 325: „(...) gdyż w naszym burzliwym czasie głosi się z wielką zawziętością przeciw Kościołowi katolickiemu tę próżną i daleką od wszelkiej pobożności ufność". 
śmierci i zmartwychwstania Chrystusa. Jak bowiem nikt bogobojny nie powinien wątpić w Boże miłosierdzie i w zasługę Chrystusa oraz w moc i skuteczność sakramentów, tak każdy, kto patrzy na siebie samego, na własną słabość i brak usposobienia, może drżeć i lękać się o swoją łaskę, gdyż nikt nie może wiedzieć z nieomylną pewnością wiary, że otrzymał łaskę Bożąa" ${ }^{23}$. W nauczaniu Soboru Trydenckiego nie odrzuca się więc pewności Bożej woli zbawienia każdego człowieka, która skutecznie dochodzi do głosu w sakramentach, lecz kwestionuje się pewność dotyczącą własnego stanu łaski i pewność własnego zbawienia. Luterskie pojęcie wiary, zgodnie z którym ponad aktem żalu to pewność przebaczenia byłaby koniecznym warunkiem owocnego przyjęcia sakramentu pokuty, uznano za nowatorstwo, które obce było dotychczasowemu nauczaniu kościelnemu. W tym kontekście rodzi się jednak zasadnicze pytanie o intencje Lutra $\mathrm{w}$ takim wyeksponowaniu osobistej wiary wierzącego, dającej pewność usprawiedliwiania i będącej niezbędnym warunkiem skutecznego przyjęcia sakramentu. Czy chciał on w ten sposób zneutralizować rytualne podejście do praktyki sakramentalnej w okresie późnego średniowiecza, pozostając jednak w zgodzie z tradycją Kościoła, czy też dokonał wyłomu w dotychczasowym sposobie rozumienia wiary, podkreślając nieodzowne znaczenie osobistej pewności odnośnie do obecności łaski jako cechy wyróżniającej prawdziwą wiarę i będącej zarazem koniecznym warunkiem usprawiedliwienia? Czy próba przeciwstawienia się koncepcji usprawiedliwienia „z uczynków” i budowanie pewności zbawienia na pewności wiary nie czyniło z niej „nowego” opus humanum w dziedzinie poszukiwania usprawiedliwienia przed Bogiem?

\section{Wiara-opus humanum?}

Luter jednoznacznie ganił jakiekolwiek wahanie grzesznika przed przyjęciem sakramentu motywowane poczuciem własnej niegodności przed Bogiem. W „Kazaniu o pokucie” (Sermo de poenitentia) przypominał, aby przystępować do sakramentu z ufnością. Twierdził bowiem, że jeśli ktoś nie chce zwracać się do Boga zanim nie będzie czysty, to nigdy do Niego się nie zwróci. Zachęcał więc do mocnej wiary, gdyż Ten, który pozwala poznać grzechy, udzieli także łaski, jeśli zostanie poproszony. Bóg właśnie dlatego pozwala nam poznać grzechy i nas usprawiedliwia, aby można było Go prosić o łaskę ${ }^{24}$.

\section{Tamże.}

${ }^{24}$ WA 1, 32141 - 322, 3: (...) accede confidenter: Quia si non ante vis orare deum (ut multi stultissime agunt) quam fueris mundus, numquam orabis. Et crede firmiter: Qui dedit tibi hanc tui cognitionem peccati te non rogante, dabit etiam gratiam oranti, immo ideo dedit cognitionem peccati et iusticiae, ut rogares gratiam. 
Wittenberski Reformator nieustannie zachęcał, aby nie spoglądać na samego siebie, lecz w wierze zwracać się w stronę Chrystusa i budować na Jego zbawczym dziele. W tym nawoływaniu przewyższa on jednak niezbędne tu zaufanie do tego stopnia, że jawi się ono już jako rodzaj samozaufania, czyli jako zaufanie do własnego zaufania. Zdaniem Lutra ten, komu mają zostać odpuszczone grzechy, winien bronić się przed wątpieniem, że jego grzechy nie są odpuszczone przed Bogiem ${ }^{25}$. Dopóki człowiek nie jest pewien przebaczenia, to faktycznie ono jeszcze nie istnieje. Nie ma bowiem przebaczenia, jeśli wierzący nie ma pewności odnośnie do niego ${ }^{26}$. Nie wystarcza bowiem samo przebaczenie grzechów i udzielenie łaski, lecz należy również wierzyć, że zostały one przebaczone ${ }^{27}$. Lutrowe wypowiedzi skłaniają się więc ku interpretacji wspomnianej pewności wiary w sensie indywidualistycznego „samoprzekonywania się”, „samozapewniania się" o odpuszczeniu grzechów, co miałoby być jednocześnie warunkiem usprawiedliwienia. W tym kontekście Luter przywołuje teologiczną zasadę, według której to nie sakrament, lecz wiara w sakrament usprawiedliwia ${ }^{28}$. Jak pisze B. Hallensleben, w kontekście Lutrowych wywodów można dostrzec, że wittenberski Reformator nie rozumie wiary tylko jako „miejsca” skutecznego działania sakramentu, lecz niejako stawia ją naprzeciw sakramentowi, przesłaniając ich wzajemne przyporządkowanie, a jednocześnie redukuje sakrament jedynie do zewnętrznej przyczyny dla odnalezienia przez człowieka pewności w jego własnej wierze $^{29}$. Wydaje się więc, że wiara urasta $\mathrm{w}$ oczach Lutra niemal do czynnika decydującego o skuteczności Chrystusowej łaski w życiu wierzącego.

Uważnemu czytelnikowi słów Lutra nie może jednak umknąć pewien rodzaj paradoksu w rozumieniu przez niego owej pewności, która z jednej strony ma wynikać z zaufania w pozostające poza nami (extra nos) dzieło zbawcze Chrystusa, skutecznie uobecniające się w Słowie, a z drugiej być pewnością dotyczącą osobistego stanu łaski. We wspomnianym już „Kazaniu o pokucie” stwierdzał on, że przyjmując absolucję w sakramencie pokuty, należy mocno wierzyć w odpuszczenie grzechów, gdyż wtedy taki stan rzeczywiście się osiągnie ${ }^{30}$. Nawet jeśli kapłan udzielałby absolucji tylko w formie żartu, a penitent mimo to wierzyłby,

\footnotetext{
${ }_{25}$ WA 1, 540, 41-42: Absolvendus vero omni studio caveat, ne dubitet sibi remissa esse apud deum peccata sua.

${ }^{26}$ WA 1, 541, 22-24: Donec autem nobis incerta est, nec remissio quidem est, dum nondum nobis remissio est, immo periret homo peius nisi fieret certa, quia non crederet sibi remissionem factam.

${ }_{27}$ WA 1, 543, 23-24: Non enim sufficit remissio peccati et gratiae donatio, sed oportet etiam credere esse remissum.

${ }^{28}$ WA 1, 324, 16-17: (...) non sacramentum sed fides sacramenti iustificat.

${ }_{29}$ B. Hallensleben, ,Das heisst eine neue Kirche bauen”. Kardinal Cajetans Antwort auf die reformatorische Lehre von der Rechtfertigung, Cath 39 (1985), 226.

${ }^{30}$ WA 1, 323, 25-27: confide, si sacerdotis obtineris solutionem, et crede fortiter te absolutum, et absolutus vere eris.
} 
że otrzymuje absolucję, to rzeczywiście doznaje odpuszczenia grzechów ${ }^{31}$. Zaś ci, którzy nie wierzą, że uzyskali absolucję, będą przeklęci ${ }^{32}$. Jednocześnie Luter przestrzegał przed fałszywą pewnością siebie (securitas), która zamyka człowieka w samym sobie. Taką pewność uważał w najwyższym stopniu za szkodliwą. Dystansował się także od rozumienia pewności łaski jako psychologicznego fenomenu i stanu. Pewność, o której pisał Luter, rozumiał on jako pewność w wierze, a tej nie należy mylić z poszukiwaniem pokoju na drodze jakiegoś wewnętrznego doświadczenia ${ }^{33}$.

Pogląd Lutra o wynikającej z wiary pewności usprawiedliwienia wynikał w dużej mierze z chęci przezwyciężenia charakterystycznej dla ówczesnej pobożności koncentracji wierzącego na sobie i własnych zasługach w myśleniu i działaniu wobec Boga i zaproponowania nowej relacji do Boga, opierającej się na wierze i zaufaniu do Niego. W Lutrowej nauce o usprawiedliwieniu pozytywne i negatywne wypowiedzi stanowią dwie strony tego samego medalu. Stwierdzenie, że usprawiedliwienie dokonuje się jedynie przez wiarę, zostało sformułowane w przeciwstawieniu (sed non) do zasługujących uczynków ludzkich. Ujawnia się w tym ujęciu duch prowadzonej wówczas polemiki, ale nie umniejsza to wagi owej pozytywnej wypowiedzi. Pozytywnie Luter naucza bowiem, zgodnie z chrześcijańską tradycją, że usprawiedliwienie dokonuje się mocą Bożej łaski. Dopełniaczowej formy „Bożej” nie należy jednak interpretować w sensie genetivus possessivus, czyli cechy usprawiedliwiającego, choć rozgniewanego Boga, przed którym nie może się ostać żaden grzesznik, lecz jako genetivus subiectivus, który wskazuje, że pełen miłosierdzia i sprawiedliwy Bóg daje człowiekowi udział w swej sprawiedliwości, mądrości i sile, jeśli ten pełen wiary ufa $\mathrm{Mu}$. „Dziełem Bożym” jest to, co czyni Bóg w nas, „mocą Bożą” - to, przez co czyni nas mocnym, „mądrością Bożą” - to, przez co czyni nas mądrym. Tym samym są także odwaga, zbawienie i chwała Boża ${ }^{34}$. Nie jest to nauka średniowiecznych teologów, lecz wynikająca z Pisma Świętego. W jej świetle człowiek nie odnajduje w sobie żadnej zasługi, która mogłaby być ,argumentem” przed Bogiem. Bóg w swej istocie nie jest jednak groźnym prawodawcą i gniewnym sędzią, lecz miłosiernym Ojcem, który składa przez Chrystusa obietnicę zbawienia i usprawiedliwienia grzesznika. Bez przyjęcia tej nauki o Bogu w wierze obietnica ta pozostałaby życiowo nieskuteczna.

${ }^{31}$ WA 1, 323, 33-35: (...), aut sacerdos non serio sed ioco absolvat, Si tamen credat sese absolutum verissime est absolutus.

${ }^{32}$ WA 1, 323, 35-26: Damnatur itaque qui nolunt confidere sese absolutos, donec certi sint se satis contritos.

${ }_{33}$ WA 1, 541, 6-7: Qui vero pacem alia via quaerit, utputa experientia intus, hic certe deum videtur tentare et pacem in re, non in fide velle habere.

${ }^{34}$ WA 54, 186, 11-13: (...) opus Dei, id est, quod operatur in nobis Deus, virtus Dei, qua nos potentes facit, sapientia [13] Dei, qua nos sapientes facit, fortitudo Dei, salus Dei, gloria Dei. 
Nowatorska perspektywa spojrzenia na relację człowieka do Boga, zaproponowana przez Lutra, nazywana bywa „skokiem wiary”. Jednak ów skok na płaszczyźnie systematyczno-pojęciowej nie został wykonany w stopniu wystarczającym. Celem Lutra było przezwyciężenie wsobnego skoncentrowania, a ostatecznie doszedł w swych teoretycznych propozycjach do wyeksponowania centralnego znaczenia osobistej wiary i zaufania jako warunków usprawiedliwienia. To skoncentrowanie na własnej wierze, bez której nie ma usprawiedliwienia, może rodzić wrażenie podobnego oderwania, czy autonomizacji w relacji do Boga, które zarzucał średniowiecznej pobożności ${ }^{35}$. Tak jak tam osobiste uczynki, tak tu osobista wiara, jako „czyn” wierzącego, miałaby mieć zbawcze znaczenie. W Lutrowym rozumieniu wiary decydujące było bowiem skoncentrowanie się świadomości na wierzącym „ja”, które miało sprawiać, że wiara stawała się niejako czynnikiem usprawiedliwiającym grzesznika. Fundamentalne znaczenie w takim pojęciu wiary odgrywało osobowe ,ja”, które stawało się niejako „partnerem” wobec Boga. W 1983 r., w Roku Lutra, w rozmowie z międzynarodowym, katolickim czasopismem „Communio”, J. Ratzinger stwierdził, że Luter dokonał radykalnej personalizacji aktu wiary, ,polegającego na podniecającym i w pewnym sensie ekskluzywnym sam na sam Boga człowiekiem" ${ }^{36}$. W wypowiedziach Lutra ta relacja przyjmowała niemal charakter przedmiotowego dysponowania łaską Chrystusa. Można dostrzec tu skłonność do traktowania Boga jako gwarancji osobistej pewności w wierze i w ten sposób wprowadzenia Go niejako w relację „zależności” od wierzącego (myślącego) ,ja”, bez którego usprawiedliwienie pozostawałoby nieskuteczne. Jednocześnie Luter tak mocno podkreślał, że pewność zbawienia opiera się na Bogu i każda wątpliwość w tym zakresie jest oznaką nieufności, że utracił z pola widzenia, iż wiara jako ludzki komponent jest także darem Boga. Pośrednio zatem Lutrowe ujęcie pewności zbawienia uczyniło z wiary ludzkie dzieło (opus humanum) - co zresztą zarzucał mu Kajetan ${ }^{37}$ - dzięki któremu człowiek dostępuje usprawiedliwienia. W takim ujęciu kryło się niebezpieczeństwo zniekształcenia zarówno obrazu Boga, jak i ludzkiej relacji do Niego, skoro dominująca rola przypadała „upewniającej” refleksji, a nie „niepewnemu” zaufaniu. A zatem z jednej strony Luter odrzucał możliwość współdziałania człowieka w sprawie swego zbawienia, z drugiej

35 B. Hallensleben, „Das heisst eine neue Kirche bauen”, 230.

36 J. Ratzinger, Luter a jedność Kościoła, w: Tenże, Kościól-ekumenizm - polityka, Poznań Warszawa 1990, 140.

${ }^{37}$ Po zapoznaniu się ze stanowiskiem Lutra doszedł on do wniosku, że oznacza ono „,budowanie nowego Kościoła" - Das heisst eine neue Kirche bauen. CAJETAn, Opuscula Omnia, Lyon 1575, 111, 3; zob. B. Hallensleben, ,Das heisst eine neue Kirche bauen”, 236; A.A. NAPIóRKOWSKI, Bogactwo łaski a nędza grzesznika. Zróżnicowany konsensus teologii katolickiej i luterańskiej o usprawiedliwieniu osiagnięty w dialogu ekumenicznym, Kraków 2000, 80; R. FrIELING, Im Glauben eins - in Kirchen getrennt? Visionen einer realistischen Ökumene, Göttingen 2006, 135. 
jednak - w swym nauczaniu o pewności zbawienia, które poniekąd przeciwstawił wolnemu działaniu Bożej łaski, to współdziałanie niejako w nowy sposób potwierdził. Dlatego też Lutrowe pojęcie wiary uznano za właściwy początek i podstawę reformacyjnego ruchu ${ }^{38}$.

Nie ulega wątpliwości, że teologiczne myślenie Ojca Reformacji naznaczone jest paradoksem. W swych reformatorskich poczynaniach Luter pragnął skoncentrować całą teologię i praktykę Kościoła w perspektywie teocentrycznej, jednak jego wypowiedzi dotyczące wiary $\mathrm{w}$ aspekcie pewności zbawienia zdają się wykazywać tendencje antropocentryczne. Przy czym nasuwający się tu wniosek należy formułować z pewną ostrożnością ze względu na Lutrową antropologię teologiczną, która nie jest wolna od aporii dotyczącej współdziałania człowieka z Bogiem. Luter rozróżnia między byciem człowiekiem a byciem osobą. Pierwsze wynika z natury, drugie konstytuuje się dzięki relacji do Chrystusa. Osobą staje się dopiero ten, kto wierzy. O zależności między wiarą a byciem osobą Luter pisał w komentarzu do Listu do Galatów, że wiara czyni z nas i Chrystusa poniekąd jedną osobę 39 . Bycie osobą zależne jest więc od relacji, która urzeczywistnia się w wierze. Pytanie, jakie się tu rodzi, brzmi: W jaki sposób owej „osobie” można przypisać akt wiary, jeśli samo istnienie osoby jako takiej jest konsekwencją wiary? I drugie: Czy wobec tego zarzut, że Luter czyni z wiary opus humanum, nie jest chybiony? Rozwiązanie widocznej tu aporii zaproponował luterański teolog W. Joest. Stwierdził on, że - owszem - w wierze to Bóg jest aktywnym podmiotem. Jednakże nawet jeśli nie jest to całkowicie samodzielna „reakcja” na Słowo, wiara pozostaje także aktem ludzkiego podmiotu, skierowanego ku Bogu i odpowiadającego na Jego Słowo ${ }^{40}$. Akt wiary można by więc przyporządkować człowiekowi, nawet jeśli Bóg jest wyłącznym autorem wszystkiego. W konfrontacji z Lutrowym pojęciem osoby wspomniana aporia nie zostaje całkiem przezwyciężona ${ }^{41}$, ale interpretacja Joesta w pewnym stopniu uprawnia do „realnego” spojrzenia na akty ludzkiego „ja”, niezależnie od przyjętej koncepcji osoby.

\section{Implikacje dla rozumienia Kościoła}

Lutrowa koncepcja wiary rodziła pytanie: W jakiej relacji pozostaje osobista, indywidualna wiara do wiary Kościoła i jakim autorytetem cieszy się Kościół

${ }^{38}$ P. HaCKER, Das Ich im Glauben bei Martin Luther, Graz 1966, 150; cyt. za: B. HallensLeBEN, ,,Das heisst eine neue Kirche bauen”, 230.

39 WA 40 I, 285, 5: Sed fides facit ex te et Christo quasi unam personam.

40 W. Joest, Ontologie der Person bei Luther, Göttingen 1967, 298.

${ }^{41}$ Por. B. WALD, Glaubensgewissheit und gute Werke, 157-158. 
w procesie usprawiedliwienia grzesznika? Implikacje nauki o usprawiedliwianiu szczególnie widoczne stały się w zakresie eklezjologii ${ }^{42}$.

W 1522 r. Luter twierdził w jednym z kazań, że chrześcijanin ma taką samą władzę jak Chrystus i trwa w Nim całe życie. Bycie chrześcijaninem oznacza trwanie w ścisłej relacji z Chrystusem - stanowienie jedności z Nim. Ten pogląd Lutra stał się bardziej konkretny w kontekście sporu z tymi, którzy większy nacisk kładli na wolność Ducha, a rzeczywistość Kościoła i liturgii postrzegali jedynie jako element zewnętrzny, z którego bez większej szkody można zrezygnować. Przedstawicieli takiego sposobu myślenia, wśród nich Andreasa Karlstadta i Tomasza Münzera, Luter określał polemicznie „marzycielami” (Schwärmer). Sam zaś zainteresowany był zachowaniem ścisłego związku między mistyką i Kościołem, między wymiarem wewnętrznym i zewnętrznym, świadom, że Kościół tkwi w rzeczywistości historycznej, a jego działalność ma też zewnętrzne znamiona ${ }^{43}$. Nie ufał poglądowi o wystarczalności jedynie wymiaru wewnętrznego, który pozostawałby bez związku ze wspólnotą. Tajemnica zjednoczenia z Chrystusem odnajduje swoje naturalne miejsce w Słowie i Sakramencie ${ }^{44}$.

Jednocześnie jednak Lutrowa koncepcja wiary nie pozostała bez wpływu na rozumienie Kościoła. O ile „dla katolików pewność wiary odnosi się do tego, co Bóg uczynił i co poświadcza nam Kościół”, o tyle dla Lutra najważniejsza była pewność nadziei (wiary) w odniesieniu do zbawienia indywidualnej osoby ${ }^{45}$ Zdecydowane podkreślanie przez niego znaczenia osobistej pewności zbawienia musiało skutkować „indywidualizacją” wierzącego w relacji do Boga. Jeśli wydarzenie usprawiedliwienia dokonuje się w osobistej relacji między Bogiem i pojedynczym wierzącym, to w perspektywie zbawienia Kościół staje się poniekąd zbędny ${ }^{46}$. Propozycja Lutra prowadziła zatem - jak zauważył P. Jaskóła - do redukcji „własnej aktywności jedynie do wiary", co w istocie podważało znaczenie jakiegokolwiek działania czy instancji w perspektywie zasługiwania na życie wieczne. Opolski teolog sformułował w tym kontekście jednoznaczny wniosek: „Koncentracja jedynie na łasce wykluczała potrzebę jakiekolwiek normy. Konkretny Kościół jako instytucja zbawcza nie tylko utracił dla niego swoje znaczenie, ale został nawet negatywnie postrzegany na tle jedynie potrzebnej wiary w Jezusa Chrystusa"47. W rezultacie Kościół przestał być postrzegany jako rzeczywista Boża wspólnota jednocząca wiernych w Ciele Chrystusa przez Ducha Świętego. Jeśli zaś Kościoła

${ }^{42}$ Por. A.A. NAPIÓRKowski, Usprawiedliwienie naczelnym kryterium, 115, 121.

${ }_{43}$ Por. M. Uglorz, Eklezjologia w teologii Marcina Lutra, w: TENŻE (red.), Teologia wiary, 222; V. LePpIN, Martin Luther, s. 23.

${ }^{44}$ G. Wenz, Kirche, Göttingen 2005, 65-67.

45 J. Ratzinger, Luter a jedność Kościoła, 139.

46 P. JASKÓŁA, Ku jedności w Chrystusie, 46.

${ }^{47}$ P. JASKÓŁA, Ku jedności w Chrystusie, 46. 
nie postrzega się jako eschatologicznej wspólnoty zbawienia, wówczas przestaje on być również widziany jako narzędzie, czy skuteczny znak zbawienia ${ }^{48}$.

Przyjmowane przez Lutra nowe rozumienie wiary i jej implikacje dla pojmowania Kościoła leżały także u podłoża jego konfliktu z ówczesnym Kościołem instytucjonalnym, zwłaszcza jego hierarchią. Konflikt ten był logicznym następstwem przyjętej koncepcji, ale jednocześnie ją wspierał i wzmacniał, gdyż zerwanie jedności z ówczesnym Kościołem prowadziło do intensywniejszego poszukiwania gwarancji zbawienia poza instytucją Kościoła. Tę pewność zbawienia miała odtąd dawać wiara ${ }^{49}$. Jednakże tam, gdzie Kościół postrzegany jest przede wszystkim jako duchowa wspólnota, jako zgromadzenie usprawiedliwionych - niewidzialne na ziemi, choć zjednoczone z Chrystusem jako głową w niebie - tam też istnieje niebezpieczeństwo lekceważenia znaczenia jego ziemskich struktur, skłaniając się, bądź przyzwalając na swoistego rodzaju outsourcing. Tak bowiem może jawić się z dzisiejszej perspektywy powierzenie zarządu Kościoła władzy świeckiej. Wydaje się, że nie był to zamierzony cel, ale immanentna konsekwencja przyjętego przez Lutra sposobu myślenia i argumentacji odnośnie do wiary i natury Kościoła.

$* * *$

Podejmując refleksję nad spowiedzią i kwestią odpustów, Luter doszedł do wniosku, że dążąc do pojednania z Bogiem grzesznik nie może spoglądać na swoje dobre uczynki, w tym na zadośćuczynienie czynione w ramach pokuty. Wówczas pozostają tylko wątpliwości i niepewność, a na tym nie może opierać się prawdziwa wspólnota z Bogiem. Luterskie spojrzenie kieruje się zatem na to, co Bóg uczynił dla nas w Chrystusie. Wiara oznacza w tej perspektywie przyjęcie pojednania z Bogiem. Jest ona osobistym zaufaniem w to, że przez Chrystusa człowiek uwalnia się od grzechu i zostaje przezwyciężone oddzielenie od Boga. Dla Lutra wiara utożsamia się z pewnością zbawienia. Gdy zaś pewność wiary prowadzi do pewności zbawienia każdego pojedynczego wierzącego, wówczas przynajmniej pośrednio - następuje wyłączenie Kościoła z indywidualnie rozumianego aktu wiary. Nawet jeśli Luter zabiegał o reformę instytucjonalnego Kościoła, to implikacje teologicznego myślenia Wittenberczyka prowadziły jednak do marginalizacji w perspektywie soteriologicznej rzeczywistości eklezjalnej.

\footnotetext{
${ }^{48}$ Warto zauważyć, że to reformacyjne novum uwidacznia się po dziś dzień w debacie dotyczącej rozumienia Kościoła jako sakramentu. Zob. np. A. BIRMELÉ, Is the Church a Sacrament?, w: P. De Mey, P. De Witte, G. Mannion (red.), Believing in Community. Ecumenical Reflections on the Church, Leuven - Paris - Walpole, MA 2013, 271-288; R. PoraDA, Kościót jako sakrament zbawienia w świetle uzgodnienia „Ku wspólnej wizji Kościoła”, „Studia Oecumenica” 14 (2014), 63-81.
}

49 Por. P. JaskóŁA, Ku jedności w Chrystusie, 226. 


\section{Bibliografia}

BARAŃSKi Ł., SoJKA J., Reformacja, t. I: Historia i teologia luterańskiej odnowy Kościoła w Niemczech w XVI wieku, Bielsko-Biała 2016.

FRIELING R., Im Glauben eins - in Kirchen getrennt? Visionen einer realistischen Ökumene, Göttingen 2006.

Hallensleben B., ,, Das heisst eine neue Kirche bauen”. Kardinal Cajetans Antwort auf die reformatorische Lehre von der Rechtfertigung, „Catholica” 39 (1985), s. 217-239.

ISERLOH E., Luther und die Kirchenspaltung, „Katechetische Blätter” 108 (1983), s. $27-41$.

JAskóŁA P., Ku jedności w Chrystusie, Opole 2016.

Joest W., Ontologie der Person bei Luther, Göttingen 1967.

LAMPE-DENSKY S., Reformation - verdrängt, verhindert, verweigert. Erneuerung und Befreiung in den frühen Jahren des 16. Jahrhunderts, Berlin 2017.

Leprin V., Martin Luther. Vom Mönch zum Feind des Papstes, Darmstadt: Wissenschaftliche Buchgesellschaft 2013.

Milerski B., Miejsce pojednania w soteriologii Marcina Lutra, w: M. UGLorz (red.), Teologia wiary. Teologia ks. Marcina Lutra i ksiag wyznaniowych Kościoła luterańskiego, Bielsko-Biała 2007, s. 107-120.

NAPIÓRKowsKi A.A., Bogactwo łaski a nędza grzesznika. Zróżnicowany konsensus teologii katolickiej i luterańskiej o usprawiedliwieniu osiagnięty $w$ dialogu ekumenicznym, Kraków 2000.

NAPIÓRKOwsKi A.A., Usprawiedliwienie naczelnym kryterium reformacyjnej odnowy Kościoła, w: TENŻE (red.), Reformatorzy a Kościół rzymski, Kraków 2017, s. 113-137.

NEUner P., Martin Luthers Reformation. Eine katholische Würdigung, Freiburg im Br. 2017.

RATzINGER J., Luter a jedność Kościoła, tłum. J. Kruczyńska, w: TENŻe, Kościót ekumenizm - polityka (Kolekcja Communio 5), Poznań - Warszawa 1990, s. $129-158$.

Uglorz M., Eklezjologia w teologii Marcina Lutra, w: TENŻE (red.), Teologia wiary. Teologia ks. Marcina Lutra i ksiag wyznaniowych Kościoła luterańskiego, Bielsko-Biała 2007, s. 217-233.

VERCRUYSSE J.E., Luthers Reformation und ihre Bedeutung für die katholische Kirche, „Zeitschrift für Katholische Theologie” 121 (1999), s. 25-44.

WALD B., Glaubensgewissheit und gute Werke. Martin Luther als Wegbereiter des utilitaristischen Moralprinzips, w: S. Kopp, W. THÖNISSEN (red.), Mehr als friedvoll getrennt? Ökumene nach 2017, Freiburg im Br. 2017, s. 141-165.

Wenz G., Kirche, Göttingen 2005. 